\title{
The Description Of Hands Shake And Voice Trembles In Conducting Class Presentation By The 4th Semester Students At Putera Batam University
}

\author{
Fasaaro Hulu. Universitas Putera Batam \\ fashulu@gmail.com
}

\begin{abstract}
The purpose of this research is to identify the students' hands shake and voice trambles in conducting presentation. The method used is qualitative describtive method. In data collection, researcher applied the closed quesionnaire through fifty students in three classes and to analyse the data by comparing and categorisation according to each its parts. And result displays in the form of text, table and chart. The result of this present research were found by the fifty students which were involved in the presentation. The first result were 33 students who got hands shake an there were 17 students who did not got hands shake in conducting presentation. the second, there were 34 students who got voice trembles and 16 students who did not got voice trembles in doing the class presentation. The most dominant faced by students in doing presentation is the voice trembles and the more dominant is the hands shake as found 16 students.
\end{abstract}

Key words: Anxiety, hands shake and voice trembles

\section{INTRODUCTION}

One of the challenging is when a stidents giving presentations. To do these, students make presentations stand out for all of the right reasons and none of the wrong ones. The students must prepare enough. each one took days or weeks of preparation. Careful preparation is essential. The amount of time to spend on planning depends on situation, but the students sometimes start early makes the students feel nervous.

Sometimes, students can get so wrapped up in delivering their presentations that they forget about the contents of the presentation material.

The students start the presentation by not telling the audience what to expect. They do not let the listeners to know what they will cover first, whether and when they stop for a break, taking questions during the presentation and so on. If these be fulfilled the audience get a clear idea of what to expect, so that they can relax and concentrate on the presentation.

Through the obseravation, there were nervous performed at the presentation and also showed nervous when they speaking. They included, During the presentation the students are practices-less. It seemed confused sometimes. It was not presenting naturally. Even they did not rehearse the presentation at multiple times before the day of presentation.Through this the students transform nervous but it was not energy into enthusiasm during the presentation. and some others are got the speechless. The students came late but not arrive early as they back from work in the evening or morning time. The setudents sometimes forget giving greeting as opening the presentation to the other friends, take several times to think and take deep breath, slides of the presentation are sometimes dark background and dark text. 
The challenging in speaking in front of people is being a problem for several speakers. Both male and female should face the about challenging with new condition and the message sent to the audiences at certain place. Especially, the challenging included some students who conduct a presentation in the class. The students were ready to stand in front of the class and speak freely related to the the topic prepared. also they speak directly without a time preparation. The condition created an anxiety for several students who convey a speech or giving a presentation in class feel fear and no self confidence. Through the observation, the students seemed were active during the class presentation and mostly were indicated that they did shaked hands and voice trembles as long the presentation in front of their friends.

Having anxiety is a panic attack, they look sweating, trembling, shortness of breath, a choking sensation, chest pain, nausea, dizziness, fear of losing your mind, fear of dying, flushing, feeling that danger is nearby and a racing heart.

Feeling anxiety comes suddenly, gripping feeling of fear and helplessness that can last for several minutes, accompanied by scary physical symptoms such as breathing problems, a pounding or racing heart, tingling or numb hands, sweating, weakness or dizziness, chest pain and stomach pain.

The hands shake faced by the students through the speaking in front of friends as they feel fear toward the students who are attending the presentation and the hands shake they got as they own in mine the mocking of their friends when they make mistakes.

The voice trembles got by the students in the class presentation as they are having heart pounds before starting sepaking and during delivering the speech. And also the hard breathing out makes their voices unclear and the voice for mostly students got thrembled. Spasmodic dysphonia is thought to be caused by abnormal functioning in an area of the brain, called the basal ganglia. Some people with spasmodic dysphonia also have vocal tremor, a shaking of the larynx and vocal folds that causes the voice to shake. Use tremble in a sentence as function as noun. Tremble means a quiver or shake, often that occurs because of fear or cold. When the voice is quivering, this is an example of a situation where there is a tremble in the voice.

Through the presentation with nothing a high-powered. The students was not confident, articulate, intelligent and well presented within their classmates. they presented infront of class but those did faze. When they are in the front to deliver a presentation, and the shakes voice would start. First, shaky voice syndrome which then spread to the hands. This one area of students presentation revealed a massive chink in their confidence.

The voice shake when the students feel nervous. It is one of the most common speech anxiety symptoms. several students suffer with a shaky voice and hands when nervous and even shaky voice anxiety long before the presentation has begun. When their brain releases adrenaline, it increases their heart rate and causes shaky hands or voice, dry mouth and sweating.

In this research, the researcher wants to figure out the anxiety related to hands shake and the voice trembles that got by the students. While the similar research stated that students feel more anxious when speaking with a native speaker rather than their peers (Çağatay, 2015). The research result by Cagatay showed the 
students feel more anxious when they speak with a native speaker but this present research icluded only their class-mates or their peers.

The hands shake and voice trembles reflects a real fear and a big problem that got by the students who present a presentation, even those decrease the students motivation in giving a speech if there no act to put off them. Therefore, this research is important to conducted to elaborate the contextual which were faced by the informants.

Lack of practicing is a common cause of fatigue, weight gain, and muscle weakness. Benign essential tremor can cause shaking of the hands and forearms and a quivering voice. Atrial flutter is an abnormality of the heart's rhythm that causes rapid and sometimes irregular heartbeats.

\section{LITERATURE REVIEW}

Presentation is a talk giving information about something, (Weber, 2008). And a good presentation delivering is as below;

a. It takes practice and effort to deliver a good presentation. But, if you know how to avoid the pitfalls, your presentations will be great.

b. Common presentation mistakes include not preparing properly, delivering inappropriate content, and speaking poorly.

c. Time spent on careful planning always pays dividends. Check the venue out, and familiarize yourself with equipment in advance to avoid possible problems.

d. Keep your content clear and concise, with visual aids to match. And make sure that you pitch it at the right level for your audience's understanding, so that your presentation doesn't patronize or bewilder. e. Remember, public speaking is a performance. Practice speaking clearly with a slower pace than your normal speech to avoid "rapid-fire" delivery. Use eye contact, body language, and gestures that complement your message to keep your audience engaged.

f. Next time you speak, avoid the mistakes outlined in this article - you'll find you can present with confidence and a clear sense of purpose

\section{Hands shaking}

Shaking is the most common hand symptom of anxiety is a restless shaking. This shaking has an obvious caused. That causes hands and legs to shake, often visibly. Tingling, burning, numbness another symptom of anxiety that is more common with panic disorder is a tingling sensation in the hands and fingers.

The hands shake and the voice trembles are general performanced by several students and those sticked to whom delevery a presentation in front of class. Accoding to Weber, Elizabeth (2008), shake is the to move backwards and forwards or up and down in quick, short movements, or to make something or someone do this.

Trembling or Shaking; When having a panic attack, a person may feel trembling sensations, especially in the arms, legs, hands, and feet. Similar to other panic attack symptoms, uncontrollable trembling and shaking are a result of the fight-or-flight reaction. This response is triggered frequently in people with panic disorder and often without cause. Fight-or-flight reactions prepare the body to either fight off or flee from a real or imagined threat in the environment. 
Excessive Sweating; As anxious feelings arise, it is not uncommon for the panic sufferer to begin to sweat. Much like other anxietyrelated symptoms, excessive sweating is part of the body's innate stress response. This reaction signals the body to be aware of feelings of danger.

Derealization and Depersonalization; During a panic attack, a person may feel disconnected from themselves and/or the surrounding environment. When experiencing these symptoms, the person may view his/her surroundings as distorted, foggy, or unfamiliar. The person may feel as though he/she is robotic, outside the self, or just going through the motions. Derealization and depersonalization tend to negatively impact the panic sufferer and often leads to increased fear, panic, and anxiety.

Numbness and Tingling Sensations; Feelings of numbness and tingling are often accompanied with derealization and depersonalization, but can also be the result of the intense feelings of anxiety that occur during a panic attack. Areas of the body may have pins and needle sensations or feel completely frozen and numb. These symptoms can occur anywhere on the body and are most often felt in the hands, arms, legs, fingers, toes, and face.

Chills or Hot Flushes'; Getting the chills is often a sign that a person is frightened. Similarly, a person's body temperature can rise when faced with a sense of danger. Feelings of anxiety may constrict blood vessels causing the person to feel hot flushes. Again, the fight-orflight response is initiated, assisting the body to build strength to fight off or run from the threat. A person going through a panic attack can also oscillate between feeling excessively hot and cold. For example, hot flushes can lead to excessive sweating, which can potentially lead to the panic attack sufferer to experience cold chills.

One of the most major barriers learners have to overcome in language classes is anxiety (Dörnyei, 2005; Ehrman,1995; Harmer, 2004; Wang \& Chang, 2010).). This problem usually appears once speakers assume their oral performance to be wrong, stupid or incomprehensible (Brown, 2001). This condition disturbs the students although they rehearsed pre-presentation time. And they cannot express themselves confidently in a social context compared to males or males might have more facilitating anxiety (Dörnyei,2005).

\section{Voice trembling}

The voice is the sounds that are made when people speak or sing (Weber, 2008). The voice, the rhythm, and the expressiveness of the speech are valued when it comes to persuading the people, (Marinho, Anna Carolina Ferreira, 2016). The voice of a speaker is the most imporatant and must be clear to make the listener catch the point of the speech.

If ones suffers from shaky voice or hands during presentations and he or she is ready to take action, get in touch. One can read book about Public Speaking: Building confidence for public speaking and presentations, or he or she could read more about our multi-award winning one-to-one presentation skills training programmes. The main thing is to address the issue head-on. Then he or she enjoys every aspect of presentation and feels calm and confident when to deliver a presentation. 
The primary anxiety symptoms of irrational and excessive fear and worry, other common emotional symptoms include:

a. Feelings of apprehension or dread.

b. Watching for signs of danger.

c. Anticipating the worst.

d. Trouble concentrating.

e. Feeling tense and jumpy.

f. Irritability.

g. Feeling mind like gone blank

\section{Controlling anxiety}

a. Breathing slowly and deeply. Anxiety can cause to breathe very quickly, which makes both the mental and physical symptoms of a panic attack even worse.

b. Stop fearful and think.

c. Think positively

d. Stand up for yourself

e. Relax your muscles

Every one should think positively and relax the muscles, in contrary, as quoted, Replicated in confident public speakers: rehearsing a negative self- image led to lower self-report performance ratings and increased anxiety during a speech (Hirsch, Mathews, Clark, Williams \& Morrison, 2006). Anxiety during the speech increase shaky hands and voice.

\section{The tips certainly helpful for shaking voice}

The main cause of shaking voice is the feeling of nervousness. Lack of clarity in mind about what to say leads to nervousness and also stammering/stuttering. The following few tips certainly helpful, by Arijit Goswami (2017):
1) Don't overestimate the audience

Don't assume that the audience is too critical and will pick out weak spots in your speech. Trust and experience it, the audience just wants to have a good time listening to you. They have actually come for you. They are not interested in being critical, but will certainly be encouraging if you show a confident face. Learn from many amateur stand-up comics who are pathetic at jokes, yet the kind of confidence they display on and off the stage makes them lovable to the audience.

2) Pause before you speak

When you stand on the stage, don't start right away. Pause for 4-5 seconds. Let everyone (even the emcee) settle down. Skim your glance over the audience and take a few deep breaths (please DON'T close your eyes for this...that looks awkward). The first 5-6 seconds must be used to calm down your nerves and to think what $\mathrm{t}$ to say. Just have a little direction in mind in which your speech will go. Don't create too many sub-topics, because the tension of covering all of them will make you more nervous.

For example, if the topic is "Women empowerment", just think of 3-4 points related to it. A quick brainstorm can give results like "What is Women empowerment", "why is it needed", "are we doing anything for it", "what else to do". Done! You have the direction now. Follow this and you will not lose content, because the moment you are done with one sub-topic, you move over the next one. 
3) Keep a water bottle

Keep a bottle of water at the lectern. Whenever you feel you are getting nervous, just walk over to the bottle while speaking, then drink some water. This will give a few seconds to calm down. Trust that, the audience will never understand that you did this deliberately. Even the most successful speakers drink water midway.

4) Ask questions

Try asking questions to the audience. For example, after speaking on what empowerment is, just ask "why do we need women empowerment? Would anyone like to answer?" Regardless of whether someone answers or not, you would have got 4-5 seconds to calm down the nerves again. And then you can be back with a bang.

5) Practice a lot

For prepared speeches, practice a lot at your home. The more you practice, the less nervous you will feel on the stage. Once the words and sentences are set well in memory and on lips, you voice will hardly shake. Practice, even if it means 10-20 repetitions. Your wonderful speech deserves that practice.

In Bartholomay, Emily M., Houlihan Daniel D., (2016) as previous research explain the speaking anxiety and promote the Public Speaking Anxiety Scale which are consist of 17 parts. But in this research taken two of the seventeen speaking Anxiety Scale by Bartholomay, at all that used to identfy the result of the research about hands shake and voice trembles performed by the students through the presentation.

The two of 17 of descriptive statistics for the public speaking anxiety scale taken that promoted by Bartholomay, Emily M., Houlihan Daniel D. (2016) are my hands shake when I give a speech and my voice when I give a speech. These both public speaking anxiety (PSA) applied to describe the students performance during the class presentation.

The second prevoius research is about negative imagery therefore appears to play a causal role in social performance and anxiety, even in confident public speakers, and so may be an important factor in public speaking anxiety (PSA) (Homer, Deeprose, \& Andrade, 2015).

Base on the two previous reserchers focused in speaking anxiety that faced by the informants in front of public. It is the similar aim as in this research about hands shake and voice trembles.

\section{METHOD}

In this research applied the qualitatif method and data collected through the observation of students presentation in two classes that involved 50 students mixed males and females at the fourth semester of Putera Batam University. The students have been learning English for four semesters. Some students take the shift classes and others are normal classes. It is supported by John W. Creswell (2009:178-181), observations are those in which the researcher takes field noted on the behavior and activities of individuals at the research site. In these field notes, the researcher records, in an unstructured or semistructured way (using some prior questions that the inquirer wants to know), activities at the research site. 
Qualitative observer may also engage in roles varying from a nonparticipant to a complete participant.

\section{Data collecting}

Data collecting through observation and recorded all the data related the hands shake and voice trembels during the presentation by performing several topics presented are education, birthday, introducing friends, home schooling and travelling. And classified them as refered to hands shake and voice trembels. Every students were asked to present in the front of class base on the topic they have choosen.

\section{Data analysis}

Data analysis in this research followed the Creswell (2009:183) states that discussion of the plan for analyzing the data might have several components. The process of data analysis involves making sense out of text and image data. It involves preparing the data for analysis, conducting different analyses, moving deeper and deeper into understanding the data after classifying the data, the data compared and put them in the fifth level speaking ability performance as propsed by Homer, at all, are not all, slightly, moderately, very and extremely. Then, each data analyse and explain in its order and clearly.

Hereby the following are the steps in analysing the data

a. Organize and prepare the data for analysis

b. Read through all the data

c. Begin detailed analysis with a coding process

d. Use the coding process to generate a description of the setting or people as well as categories or themes for analysis e. Advance how the description and themes will be represented in the qualitative narrative passage to convey the findings

f. A final step in data analysis involves making an interpretation or meaning of the data

\section{Data displays}

The basic procedure in reporting the results of a qualitative study are to develop descriptions and themes from the data, to present these descriptions and themes that convey multiple perspectives from participants and detailed descriptions of the setting or individuals as stated by John W. Creswell (2009:193). Data displays in this research is described in the form of table, chart and elaborate them in texts.

\section{FINDING}

The Hands shake in Conducting Class Presentation by the Students

The seventeen data below are found through 50 students and described in the table

Table 3.1 no hands shake at all

\begin{tabular}{|c|c|}
\hline $\begin{array}{c}\text { Hands shake } \\
\text { performance }\end{array}$ & $\begin{array}{c}\text { Number of } \\
\text { stdents }\end{array}$ \\
\hline not at all & 17 \\
\hline
\end{tabular}

From the table above, the 14 data found through the students which are consist of women and three men. During the presentation in the class, the seventeen students are not feeling shaking hands as they were often spoke and gave presentation in several places such in the learning class process, in the meeting in the company where they work everyday. In short, the students feel relax and used to speak in front of people. 
The following data were consist of thirteen data related to slightly hands shake and display through table.

Table 3.2 slightly hands shake

\begin{tabular}{|c|c|}
\hline $\begin{array}{c}\text { Hands shake } \\
\text { performance }\end{array}$ & $\begin{array}{c}\text { Number of } \\
\text { students }\end{array}$ \\
\hline Slightly & 13 \\
\hline
\end{tabular}

The thirteen data in the table above collected from the students. They did the presentation as usual and felt a little hands shake in front of their friends. the both left and right hand seemed little tremble when they convey the presentation. They felt slightly hands shake when they started the presentation untill the end. In addition, the students felt the hands shake was in the begining in the opening and self-introduction.

In this table below, there are elevent data related to the students presentation in moderately

Table 3.1 hands shake moderately

\begin{tabular}{|c|c|}
\hline $\begin{array}{c}\text { Hands shake } \\
\text { performance }\end{array}$ & Number of stdents \\
\hline Moderately & 11 \\
\hline
\end{tabular}

Base on the seven data from the women and the fourth students from the men, they started the presentation with self confidence but it seemed that they able present the presentattion moderately in the class. Sometimes, they felt hands shake and did not. It seemed that when they convey the presentation from the starting, the middle and the end was better performance with friends in the class.

In the following table, there were found seven students who felt hands shake through the presentation
Table 3.1 . hands shake related to very

\begin{tabular}{|c|c|}
\hline $\begin{array}{c}\text { Hands shake } \\
\text { performance }\end{array}$ & Number of stdents \\
\hline Very & 7 \\
\hline
\end{tabular}

In the table above, there were six students, women and one student, man who join the class presentation. In the staring of the presentation in the class with their friends, one by one seemed that was not usual. There was something uncovenient at the time of the presentation. So, the presentation was not done perfectly as they got a very hands shake during the presentation in the front of the class.

In this table below shows the two numbers of data which were taken from the students.

Table 3.1 extremely hands shake

\begin{tabular}{|c|c|}
\hline $\begin{array}{c}\text { Hands shake } \\
\text { performance }\end{array}$ & Number of stdents \\
\hline Extremely & 2 \\
\hline
\end{tabular}

Base on the data from the table above, there were found two students of all who felt the most hands shake through the class presentation. In the begining of the presentation was known the perfotmance which was going unsatisfied for the listener. The two students seemed fear of being seeing by the other sstudents who attended the presentation. The wo hands tramble was not straight and calm but it moved around such a person who felt fever which two hands were cold and tremble fron the beginning to the end of the presentation. 


\section{The Hands Voice Trembles in Conducting}

\section{Class Presentation by the Students}

In the data below were taken from the fifteen students. Those are presented in the form of table

Table 4.1 no voice trambles

\begin{tabular}{|c|c|}
\hline $\begin{array}{c}\text { Voice } \\
\text { trembles } \\
\text { performance }\end{array}$ & Number of stdents \\
\hline not at all & 16 \\
\hline
\end{tabular}

From the sixteen data above were found fifteen students refered to the girls and one student refered to the boy. The sixteen students did not feel any reluctant and voice trable when they convey the presentation in the class. It was from the beginning of the presentation went smoothly and perfect. There were not foung tramble voice that spoke by each student until they finished the presentation. Every students enjoyed the presentation and speak clearly to the listener.

The table below describes the 20 data which were taken from the students

Table 4.2 slightly voice tramble

\begin{tabular}{|c|c|}
\hline $\begin{array}{c}\text { Voice } \\
\text { trembles } \\
\text { performance }\end{array}$ & Number of stdents \\
\hline Slightly & 20 \\
\hline
\end{tabular}

From the data in the table above, there were found twenty students felt a little voice trembles. In the beginning of the presentatioon seemed fine but the performance showed a little sound which unclear. The message which were sending to the listener in the same time were nice but some a few students trying asking another friend to comlete a little about what thay had just been spoken in front of the class.
This data in the table were taken from the students as below

Table 4.3 modeartely voice trembles

\begin{tabular}{|c|c|}
\hline $\begin{array}{c}\text { Voice } \\
\text { trembles } \\
\text { performance }\end{array}$ & Number of stdents \\
\hline Moderately & 10 \\
\hline
\end{tabular}

Base on the number of the students in the table above, there were found ten students refered to moderately voice trembls. At the starting of the presentation, the sudents introduce their self and the topic of the presentation they had. Then they conducted the presentation from the beginning until finished good enough. There were listened the voice little trembles but the could made it fine.

The data below are three students who felt the extremely voice trembles in the class presentation

Table 4.4 the very voice trembles

\begin{tabular}{|c|c|}
\hline $\begin{array}{c}\text { Voice } \\
\text { trembles } \\
\text { performance }\end{array}$ & Number of stdents \\
\hline Very & 1 \\
\hline
\end{tabular}

From the data above, the data collected through obsevation among the students. There were three students who felt the most tremblevoices such a frightened person. In the beginning of the presentation, the three students convey the material shake slightly the voice, like feeling cold and face seemed frightened. They most focus looking at one point forward and looked around sometimes. In the end of the presentation, the extremely voice trembles were constantly appeared. 


\section{DISCUSSION}

a. The Students Got Hands Shake At Giving Presentation

The chart below are the described the fifth data hands shake in speaking faced by the students

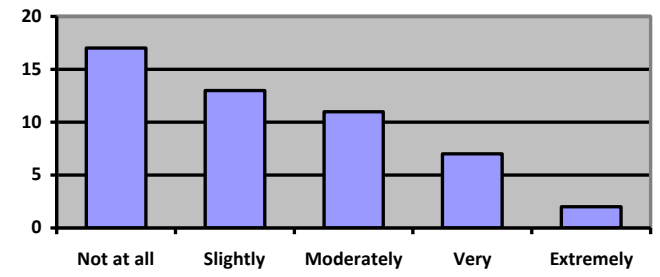

Base on the chart above, there were found fifty students who attended the presentation and each of them has different hands shake level. There were 17 data related to the not at all shaking hands, 13 data for slighly shaking hands, 11 data for moderately shaking hands, seven data for very shaking hands and 2 data for extremely shaking hands. In short, from the 50 students who were involved to the presentation were found 33 students got shaking hands. While the rest 17 students did not perform shaking hands during the presentation.

\section{b. The Students Got Voice Trembles}

This chart below are the described the fifth data for voice trambles in speaking faced by the students

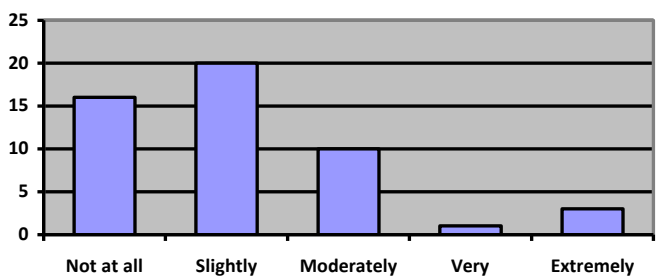

From the chart above, there were 50 students who joined the presentation and they had the different voice performanced in doing the presentation. there were 16 students related to not at all trembling voice, 20 students for slightly trembling voice, 10 students for very trembling voice, 1 students for very trembling voice and 3 students for extremely trembling voice. So, from the 50 students who were attended the presentation in class, there were 34 students got trembling voice in conducting presentation. while there were 16 students who did not got trembling voice in doing the class presentation.

\section{CONCLUSION}

The hands shake and the voice trembles are problems which were faced by mostly students during the presentation in the class. The hands shake got by the students are more than the number of students who did not hands shake at the presentation. among the 50 students who involved in the class presentation showed that, there were 33 students who got hands shake during the class presentation and the 17 students showed nothing about shaking hands in the presentation.

And also the voice trembles got by the students who attended the presentation. from the 50 students there were 34 students who performed the voice presentation. those numbers of the students who performed the voice trembles in the presentation time were more than the students who did not perform the voice trembles. And there were 16 students performed the voice trembles in the presentation.

The more number of both stundents performance through the presentation is the voice trembles are 34 students while the hands shake are 33 students.

The higest quantity of both stundents performing nothing through the presentation is hands shake are 17 students while 16 students refer to voice trambles. 


\section{REFERENCES}

Bartholomay, Emily M., Houlihan Daniel D., 2016. Public Speaking Anxiety Scale, Minnesota State University, Mankato, United States: Elsevier

Brown, H. D. (2001). Teaching by principles. NewYork: Pearson Education

Çağatay, S. (2015). Examining EFL Students' Foreign Language Speaking Anxiety: The Case at a Turkish State University. Procedia - Social and Behavioral Sciences, $\quad 199, \quad 648-656$. https://doi.org/10.1016/j.sbspro.2015.07.5 94

Creswell, J.W. (2009). Research Design. Third Edition. Sage Publications, California.

Dörnyei, Z. (2005). The psychology of the language learner: Individual differences in second language acquisition.New Jersey: Lawrence Erlbaum Associates, Inc

Ehrman, M. E. (1995). Understanding second language learning difficulties: Looking beneath the surface.Thousand Oaks, CA: Sage

Harmer, J. (2004). The Practice of English Language Teaching (6th ed.). Harlow: Pearson Education Limited.

Homer, S. R., Deeprose, C., \& Andrade, J. (2015). Negative mental imagery in public speaking anxiety: Forming cognitive resistance by taxing visuospatial working memory. Journal of Behavior Therapy and Experimental Psychiatry. https://doi.org/10.1016/j.jbtep.2015.05.00 4

Marinho, Anna Carolina Ferreira, E. (2016). Fear of Public Speaking: Perception of College Students and Correlates. Journal of Voice, 5.

https://doi.org/10.1016/j.jvoice.2015.12.0 12

Wang, L. J., \& Chang, H. F. (2010). Applying innovation method to assess English speaking performance on communication apprehension. Belt Journal, 1(2), 147-158 
Weber, Elizabeth (2008). Cambridge Advance Learner's Dictionary, 3rd ed. Cambridge: Cambridge University Press

https://www.verywellmind.com/top-symptomsof-panic-attacks-2584270, (accessed on March 1st, 2018)

https://www.quora.com/How-do-I-stop-myvoice-from-shaking-when-publicspeaking-How-do-I-calm-my-nervesdown, Arijit Goswami, (2017) as Public speaker and mentor, Toastmaster, CC, CL, ALB, (accessed on March 1st, 2018)

https://www.mindtools.com/pages/article/present ation-mistakes.htm, Avoiding Common Pitfalls in Your Presentations, (accessed on March 1st, 2018) 